\title{
Forest Certification for Sustainable Forest Management in Cameroon: Myth or Reality
}

\author{
Nghobuoche Frankline ${ }^{1,2, *}$, Ngoufo Roger ${ }^{1,3}$, Tatuebu Tagne Claude ${ }^{1}$, Louis Defo ${ }^{1}$, \\ Kiming Ignatius Ngala ${ }^{1}$ \\ ${ }^{1}$ Department of Geography, University of Yaoundé I, Yaounde, Cameroon \\ ${ }^{2}$ Regional Research Centre for Sustainable Development (RReCSuD), Yaounde, Cameroon \\ ${ }^{3}$ Cameroon Environmental Watch (CEW), Yaounde, Cameroon
}

\section{Email address:}

nghobuochefrank@gmail.com (N. Frankline), ngoufocew08@yahoo.fr (N. Roger), claudetagne86@gmail.com (T. T. Claude), defols@yahoo.fr (L. Defo), ignatiusngalakiming@gmail.com (K. I. Ngala)

${ }^{*}$ Corresponding author

\section{To cite this article:}

Nghobuoche Frankline, Ngoufo Roger, Tatuebu Tagne Claude, Louis Defo, Kiming Ignatius Ngala. Forest Certification for Sustainable Forest Management in Cameroon: Myth or Reality. International Journal of Environmental Protection and Policy.

Vol. 8, No. 6, 2020, pp. 105-116. doi: 10.11648/j.ijepp.20200806.11

Received: September 29, 2020; Accepted: October 16, 2020; Published: November 4, 2020

\begin{abstract}
Forest certification is one of the best known voluntary environmental programs for sustainable forest management in the world today. The main objective of this study is to assess the role of forest certification in forest management in Cameroon. Primary and secondary research approaches were used to sought data and information from relevant governmental legislation and reports, certification systems website as well as interviews with staffs of the ministry, forest concessions and certification schemes. Analysis revealed that the number of Forest Management Units in Cameroon increased from 105 in 2004 to 120 in 2019 while surface area increased from 6,961,700 hectares to 7,073,056 hectares. The results also indicated that the number of concessions certified by FSC increased from 1 in 2005 to 9 certificates in 2010 and to 18 in 2014 . The number later dropped to 16 in 2015, 13 in 2017 and 7 in 2019. The FSC certified surface area increased from 820,630 hectares in 2012 to $1,013,374$ hectares in 2013/2014 and a drastic drop to 940,945ha in 2015. The peak period was from June-November 2017 with 1,130,301 hectares while in 2018/2019 the surface area reduced to 341,708 ha. Many factors impeded the growth of forest certification in the Cameroon.
\end{abstract}

Keywords: Forest Certification, Sustainable Forest Management, Forest Management Unit, Cameroon

\section{Introduction}

A number of efforts have been adopted in an attempt to curb the problem of forest degradation and deforestation, which stands tall among the major environmental and social concerns [1-3]. Between 2000 and 2003 alone, the area of certified forests worldwide doubled to approximately 150 million hectares $[4,3]$. The United Nations estimates that 355 million hectares of forests has been certified globally, approximately nine per cent of the total global forest area. Programme for the Endorsement of Forest Certification Schemes (PEFC) certification covers 230 million hectares and the Forest Stewardship Council (FSC) certifies around 135 million hectares in the world [5]. Given the global deforestation rates of about 13 million hectares per year, and an unknown but considerable higher rate of tropical forest degradation, increase efforts of maintaining forests and their biodiversity through improved forest management is an important global priority [6]. The number of certified forest management units covered by Forest Stewardship Council (FSC) certification increased from 48 in 2012 to 53 in 2019 while the number of chain of custody certificates increased from 140 within the same periods $[7,8]$.

Concessions in Central Africa covers 50 million ha for around $165 \mathrm{M}$ ha of dense forest 10 million $\mathrm{m}^{3}$ of round wood each year [9]. Industrial logging is one of the most extensive uses of land in Central Africa, with almost 450,000 $\mathrm{km}^{2}$ of forest currently under concession (about a quarter of 
the total lowland tropical forests). The formal logging sector in Central Africa produces an average of 8 million $\mathrm{m}^{3}$ of timber each year, mostly for exports to Europe and Asia. The industrial logging sector is one of the major contributors to the Gross Domestic Product (GDP) and a vital employer for most Congo Basin countries [10]. The forest in Cameroon covered 22 million hectares being $46 \%$ of total land area. Permanent forest estate occupies 11.78 million hectares while Non-permanent forest estate cover 10.22 million hectares [11]. The forest sector contributed USD 695.3 million in $2011 ; 2.8 \%$ of the GDP in 2011 [12] and $2.07 \%$ of GDP in 2017 [13]. The sector was the 38th highest exporter of EUTR products globally in 2017 by weight $(\mathrm{kg})$ and 58th highest exporter of EUTR products globally in 2017 by value (USD) [14].

Based on the African Timber Organisation-International Tropical Timber Organisation principles, criteria and indicators, the Pan African Forest Certification (PAFC) standards have been adapted in Cameroon and termed Cameroonian association of Pan African Forest Certification (PAFC). It has also been accepted as a Pan European Forest Certification (PEFC) member in 2007 for Cameroon being only the second country in Africa after Gabon. FSC certification started in Cameroon in 2005 and by mid-2008, there were seven FMUs certified under FSC with 5.6 million hectares forest area. Bureau Veritas (then Eurocertifor) developed the "Origin and Legality of Timber" (OLB) label in 2003 and awarded the first certificate in 2004. By the end of 2009, other FMUs where certified under "Origin and Legality of Timber" (OLB). Commercial timbers species are found in densities less than 1 per 100 hectares in a FMU are legally protected in Cameroon [15]. The VPA/FLEGT of the European Union was signed by the Cameroon government in 2010 [16]. Among existing forest certification schemes, the one offered by the Forest Stewardship Council (FSC) is the most prominent for the certification of responsible forest management in the tropics [17-20]. What emerged from the issues raised are many shortcomings in forest certification in Cameroon is mainly the fact that forest certification is a mechanism for forest monitoring, tracing and labelling timber, wood and pulp products and non-timber forest products, where the quality of management from environmental, social, and economic perspectives is judged against a series of agreed standards [21].

This article seeks to contribute by filling the knowledge gap by assessing the contribution of forest certification to sustainable forest management in Cameroon. Several aspects were dwelled on in this paper, 1) the evolution of Forest Management Units (FMUs) from 2004-2019 2) the evolution of number of certificates and certified surface area 3) the change in FSC Forest Management and Chain of Custody certificates and factors influencing the change in certified surface area in Cameroon. We focus on FSC certification due to the fact it was the first certification system in Cameroon and has been facing serious downturn in recent years.

\section{Materials and Method}

In this study, the authors made use of overwhelmingly qualitative research methodology for the study. However, the study also makes use of basic quantitative tools like computing percentages and averages. Both primary and secondary research approaches were used for this study. A number of steps that must be taken and decisions made to create a review that meets the requirements for publication. The authors sought information from relevant governmental legislation and reports, company documents, industry magazines, newsletters (WWF), working papers from government and civil society, data and information from certification schemes like FSC, Bureau Veritas, Rainforest Alliance and Societe General de surveillance as well as peerreviewed literature and websites. The data on FSC certified surface area was collected from monthly facts and Figure published by FSC from 2012 to 2019 . General data and information on FSC certification and surface area covered by traceability systems (OLB SGS and Rainforest Alliance in Cameroon was gotten from systems websites. Data on Forest management units in Cameroon from 2014 to 2019 was collected from the World Resource Institute (2004-2019) and the direction of forest of the Ministry of Environment and Wildlife [12].

Primary data was obtained through interview with some representative and staffs of the certification systems, logging companies, Ministry of Forestry and Wildlife (MINFOF) as well as international Non-Governmental Organisations (NGO) based in Yaounde. Interviews were conducted between June and July 2020. The questions targeting the major factors impeding FSC Certification in forest concessions in Cameroon. The data from the World Resource Institute (WRI) was used to draw maps to show the evolution of forest management units and certified concessions in Cameroon 2004-2019.

\section{Results}

\subsection{State Forest Management Units in Cameroon}

The forest sector in Cameroon is managed by Law No 94/01 of 20 January 1994 that lay down forestry, wildlife and fisheries regulations. The decree of implementation followed on the 23 August 1995. The sector contributed substantially to about $4 \%$ of GDP in 2013, created 13,000 formal and 45,000 direct informal jobs while providing about €62 million of annual revenues to the state's coffers in Cameroon [22, 23].

Forest Management Units (FMUs) were created under the Law $\mathrm{N}^{\circ}$ 94/01 of $20^{\text {th }}$ January 1994 laying down the forest code in Cameroon. FMUs are forest management units zoned within the Permanent Forest Domain (forests that are zoned for biodiversity conservation and sustainable management). They are allocated by a competitive bidding process for a 15year period and require a forest management plan approved by the relevant administrative authority. Forest Concessions are single managed units, which may include one or more 
FMUs, not to exceed 200,000 ha [24]. Forest concessions in

to 2019 (Table 1).

Cameroon witnessed an increases over the years from 2004

Table 1. Evolution of Forest Management Units (FMU) in Cameroon 2004-2019.

\begin{tabular}{|c|c|c|c|c|c|c|c|c|c|}
\hline \multirow{2}{*}{\multicolumn{2}{|c|}{ Category }} & \multicolumn{4}{|c|}{ Number of FMUs } & \multicolumn{4}{|c|}{ Change in the number of FMUs } \\
\hline & & \multicolumn{2}{|c|}{$2004 \quad 2009$} & 2014 & 2019 & 2004-2009 & \multirow{2}{*}{$\begin{array}{l}\mathbf{2 0 0 9 - 2 0 1 4} \\
01\end{array}$} & \multirow{2}{*}{$\begin{array}{l}\text { 2014-2019 } \\
05\end{array}$} & 2004-2019 \\
\hline Forest Management Units ( & MUs) & 105 & 114 & 115 & 120 & 09 & & & 15 \\
\hline Allocated & & 72 & 101 & 111 & 112 & 29 & 10 & 01 & 40 \\
\hline Unallocated & & 24 & 13 & 10 & 08 & -11 & -3 & -2 & -16 \\
\hline \multirow{2}{*}{ Category } & \multicolumn{5}{|c|}{ Surface area of FMU (hectare) } & \multicolumn{4}{|c|}{ Change in surface area of FMU (hectare) } \\
\hline & 2004 & & 2009 & 2014 & 2019 & 2004-2009 & 2009-2014 & 2014-2019 & 2004-2019 \\
\hline $\begin{array}{l}\text { Forest Management Units } \\
\text { (FMUs) }\end{array}$ & $6,961,700$ & & $7,500,881$ & $6,785,464$ & $7,073,056$ & 539181 & $-715,417$ & 287592 & 111,356 \\
\hline Allocated FMUs & $4,946,900$ & & $6,515,529$ & $6,206,448$ & $6,582,446$ & $1,568,629$ & $-309,081$ & 376,018 & $1,635,566$ \\
\hline Unallocated FMUs & $1,147,800$ & & 985,352 & 579,016 & 490,610 & $-162,448$ & $-406,336$ & $-88,406$ & $-657,190$ \\
\hline
\end{tabular}

Source: Data base WRI and MINFOF (2004-2019) [25-28].

It can be observed from the analysis that the number of Forest Management Units in Cameroon increased from 105 in 2004 to 120 in 2019. The surface area covered by FMUs in Cameroon increased from 6,961,700 hectares in 2004 to $7,073,056$ hectares during the same period; an increase of 111,356 ha. In 2011 there were a total of 111 FMUs (7.1 million ha, representing about $15 \%$ of the national area). 87 of them (5.5 million ha) were allocated to logging in the form of logging concessions, including 72 operating on the basis of a management plan approved by MINFOF. These covered an area three times the size of 2004 growing from 1.5 million to 5 million ha. Table 1 also shows that the allocated surface area covered by FMUs increased from 4,946,900 hectares in 2004 to $6,582,446$ hectares in 2019 (Figurer 1).

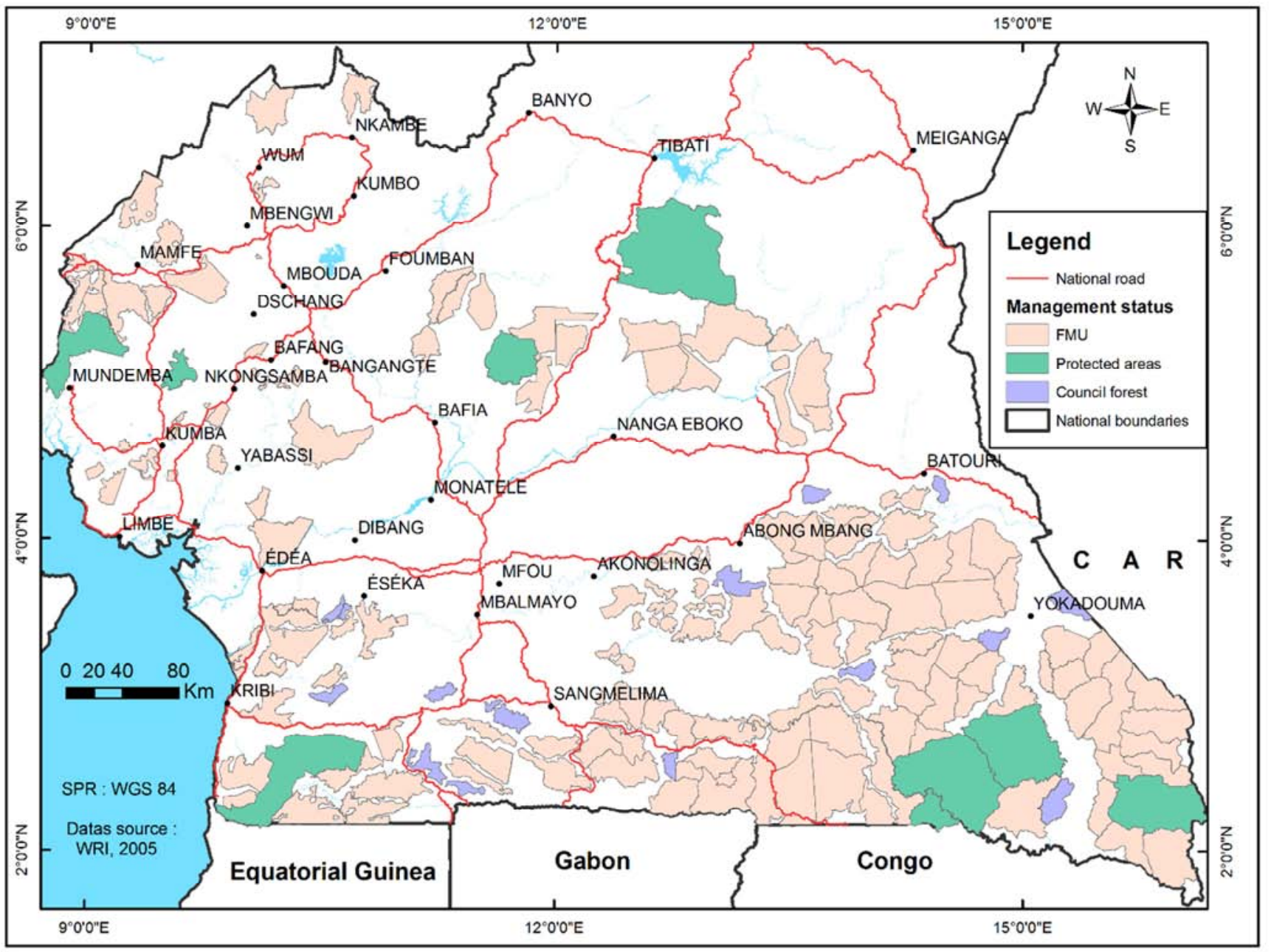

(a) State of management in 2004 . 


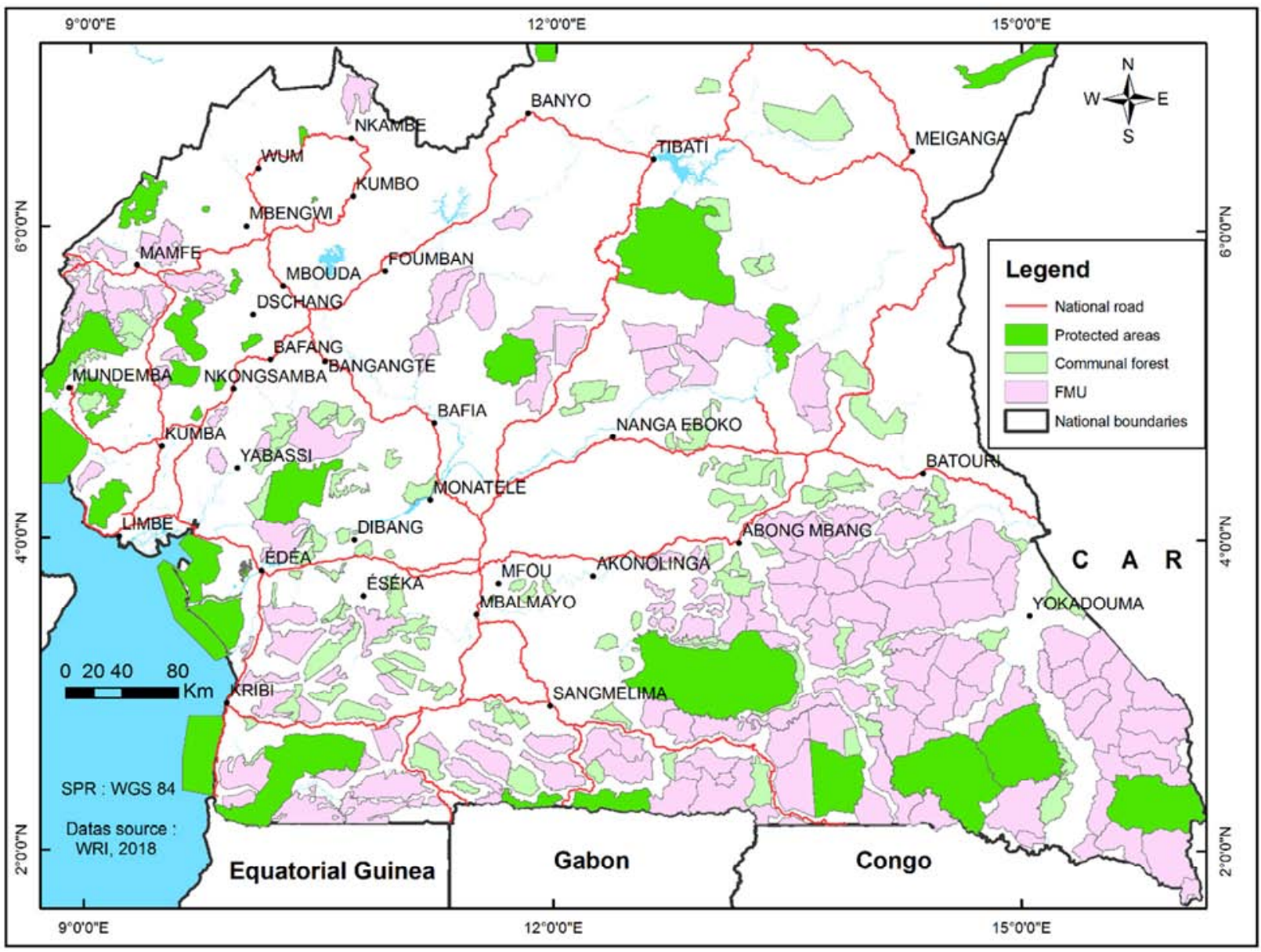

(b) State of management in 2018.

Figurer 1. Forest concessions and protected areas in Cameroon 2004 and 2018.

Source: WRI, $2004 \& 2018$.

\subsection{Evolution of Forest Certification in Cameroon}

The first FSC certificate registered in Cameroon in 2005 with the certification of a FMU from the Wijma Company, represent 42,800 ha. Since then, other companies have also embarked on this initiative, such as the companies Pallisco, Decolvenaere, TRC and SEFAC (Table 2). As of mid-2008, the total area of the seven certified FMUs in Cameroon was about 560000 ha, with several other companies well advanced in the process. Certification goes well beyond the legal technical prescriptions required for management plans, but we considered only issues directly related to management plans as a complement to the previous findings and further illustration of the legal weaknesses persisting in the sustainable management of the Cameroonian forests [23].

The success of certification has spawned a number of different approaches, which largely reflect the interests of their main stakeholders [29]. Five certification and legality schemes were identified in Cameroon with different principles, criteria and matrix. They included, the Forest Stewardship Council (FSC), the Origin and Legality of Wood (OLB) Certification System, Forest Law Enforcement, Governance and Trade (FLEGT), African Timber
Organization (ATO) and the Program of Endorsement of Forest Certification (PEFC). Others include the Rainforest Alliance (RA) legality verification programme as a progressive, two-tiered system in which companies began with Verification of Legal Origin (VLO) and moved to Verification of Legal Compliance (VLC). SGS's Timber Traceability and Legality Verification System (TTLV) was developed to improve traceability and forest management by using technology to trace the movement of timber and monitor financial flow.

When the traceability system is installed, it can be checked by an independent body, certifying the legal origin of the timber. In Cameroon, two systems are currently used by forestry companies: the certificate of Origin and Legality of Wood (OLB by BVQI-Eurocertifor) and the attestation of Timber Legality and Traceability Verification (TLTV by Société Générale de Surveillance - SGS). Currently, 21 FMUs benefit from one of these certificates, corresponding to an area of approximately 1.3 million hectares, or nearly $25 \%$ of the total area allocated (Table 2). In some cases, it is the commitment of these companies towards sustainable development certification (of the FSC type) which led them to develop and certify these traceability systems. 
Table 2. Certification and traceability within attributed FMU $U^{l}$ in 2011.

\begin{tabular}{lllll}
\hline System & Situation of FMU $^{2}$ & Number & Surface $^{2}$ area $^{\mathbf{3}}$ (ha) & Percentage of total surface area \\
\hline FSC certification & Traceability & $1^{4}$ & 42,800 & 1 \\
& Completed pre-audit & 15 & $1,100,500$ & 20 \\
& Non-engaged procedures & 74 & $4,413,900$ & 79 \\
TOTAL & Attributed & 90 & $5,557,200$ & $100 \%$ \\
Traceability & Verified OLB $^{5}$ & 11 & 704,500 & 13 \\
& Verified SGS $^{6}$ & 10 & 663,300 & 12 \\
TOTAL & Not controlled & 69 & $4,189,500$ & 75 \\
\hline
\end{tabular}

Many companies take part in two processes of FSC certification and OLB or SGS traceability.

Certification and traceability will settle at the level of forest concessions.

The surface area indicated on the table were rounded to the nearest 100 ha.

Wijma group, concession No 1006.

Origin and legality of Wood by BVQI-Eurocertifier.

Société Générale de Surveillance using its program Timber Legality and Traceability Verification (TLTV).

From Table 2 it can be observed that in 2011, there were a total of 111 FMUs ( 7.1 million ha, representing about $15 \%$ of the national area). 87 of them ( 5.5 million ha) were allocated to logging in the form of logging concessions, including 72 operating on the basis of a management plan approved by MINFOF. These covered an area three times the size of 2004, growing from 1.5 million to 5 million ha. Forest concessions certified by the Forest Stewardship Council (FSC) have also increased significantly. In June 2011, 14 FMUs having FSC certification; covered an area of just over 1 million ha (13\% of the total area of FSC-certified concessions in Africa) and were operated by five different conglomerates. In 2015, 95 were identified as classified having an area of 5,707,897 Ha, but also 21 declared and in the process of regularization, or a total of 116 for a final area of $6,878,226$ ha (or $14.5 \%$ of the territory). 36 FMUs covering an area of 2.35 million ha have been certified by different systems (FSC, OLB, TLTV, CoC). Of the FMUs in activity, 33 have obtained a definitive agreement and are therefore committed to an environmental and social management process that respects the imposed standards (Table 3 ).

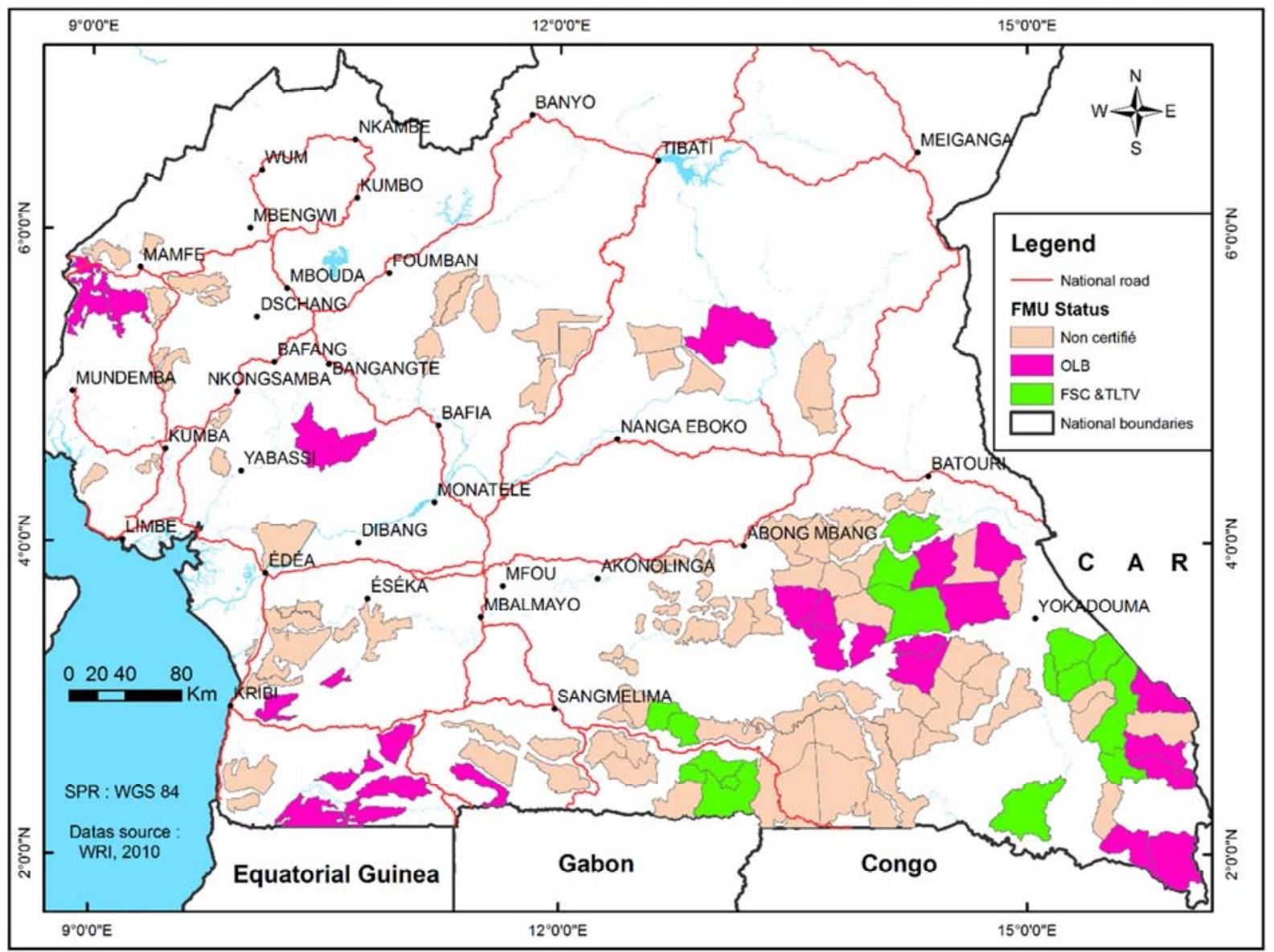

a) Certified forest concessions in Cameroon 2004 . 


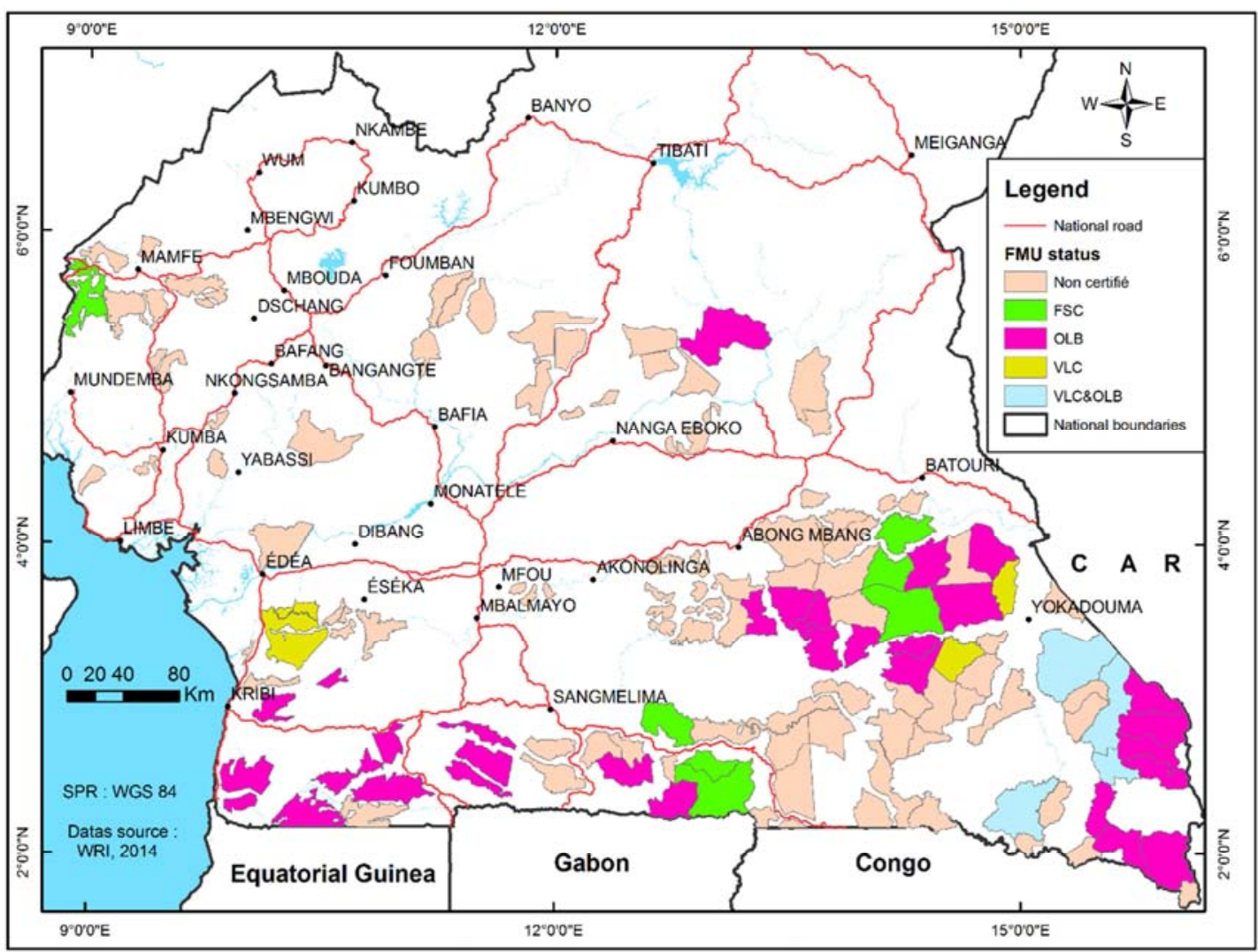

b) Certified forest concessions in Cameroon 2010 .

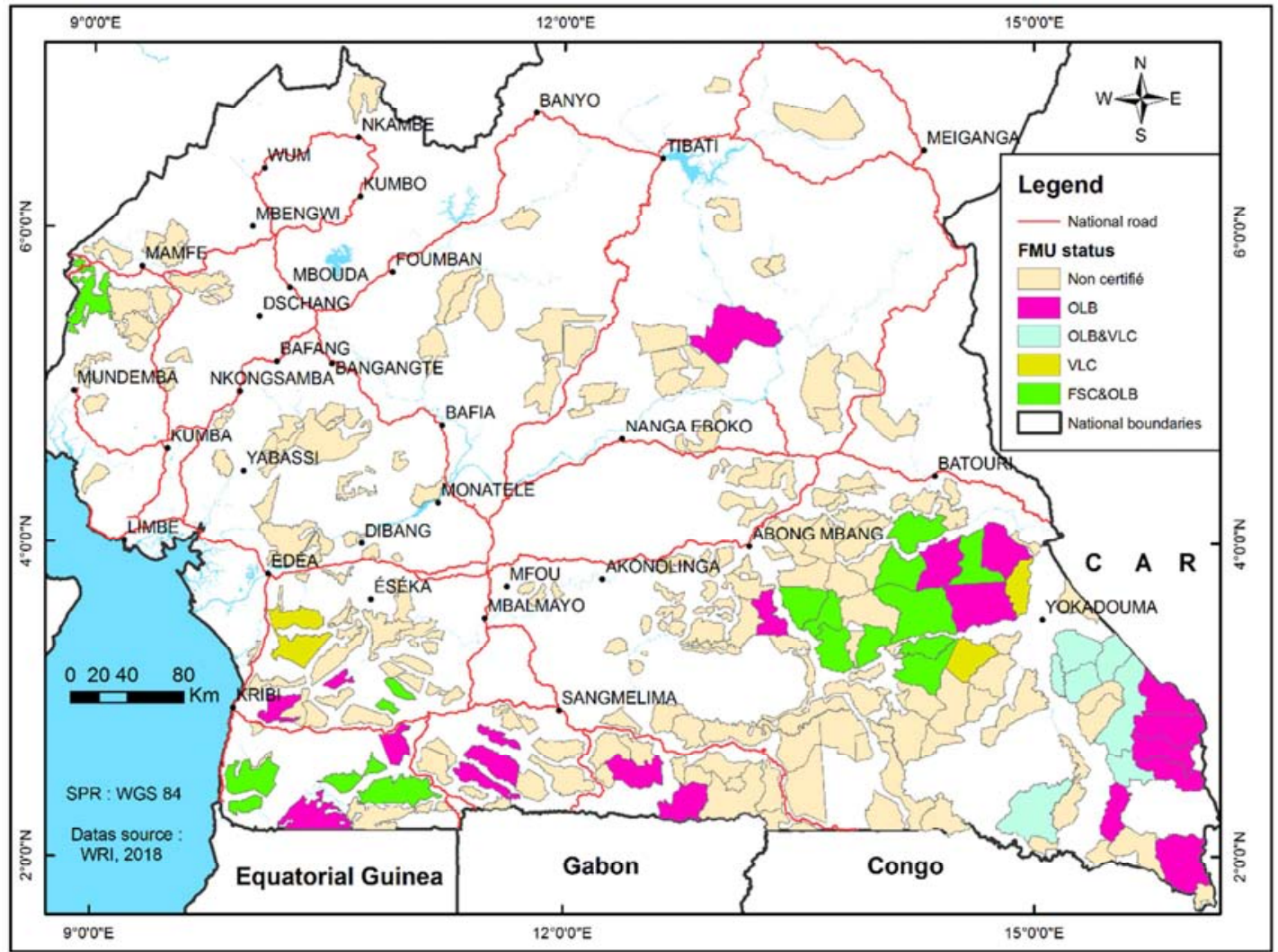

c) Certified forest concessions in Cameroon 2018.

Figurer 2. Certified forest concessions in Cameroon 2010, 2014 \& 2018. 
Table 3. Forest certification systems in Cameroon in 2017.

\begin{tabular}{llll}
\hline No & Certification System & Number & Surface area (ha) \\
\hline 1 & Forest Stewardship Council (Forest management) & 14 & $1,039,907$ \\
2 & Origin and Legality of Wood (OLB) (Origin and legality of Wood) & 30 & $2,030,214$ \\
3 & Verification of Legal Compliance (Origin and legality of Wood) & 03 & 239,574 \\
4 & Bureau Veritas-Control Wood (chain of traceability) & 02 & 117,967 \\
5 & Société Générale de Surveillance - Control Wood (Chain of traceability) & 02 & 183,330 \\
6 & SW- Control Wood (chain of traceability) & 02 & 140,099 \\
\hline
\end{tabular}

Source: MINFOF (direction of forest), 2017.

Figurer 2 revealed that out of the 111 forest concessions existing in 2010, there were 26 OLB certified concessions in Cameroon. The Figurer equally shows the existence of 16 FSC and TLTV forest concessions in 2010. The number of certified forest concessions in Cameroon increase to 115 in 2014. Among the 115 concessions, FSC had 5 forest management units and 13 chain of custody certificates while OLB certification system had 30 forest management and chain of custody certificates. Five forest concessions in 2014 were certified by the Rainforest Alliance (RA) that began with Verification of Legal Origin (VLO) and moved to
Verification of Legal Compliance (VLC). The OLB and Rainforest Alliance jointly certified four forest concessions (Figurer 2). The number of forest concessions in Cameroon further increased to 117 (7,030,484 hectares) in 2018. Among the 117 forest concessions existing in the country, 16 were jointly certified by FSC and OLB. The forest concessions jointly certified by OLB and Rainforest Alliance (RA) Smart Wood increased from four in 2014 to seven in 2018. OLB certified concessions decreased from 30 in 2014 to 20 in 2018.

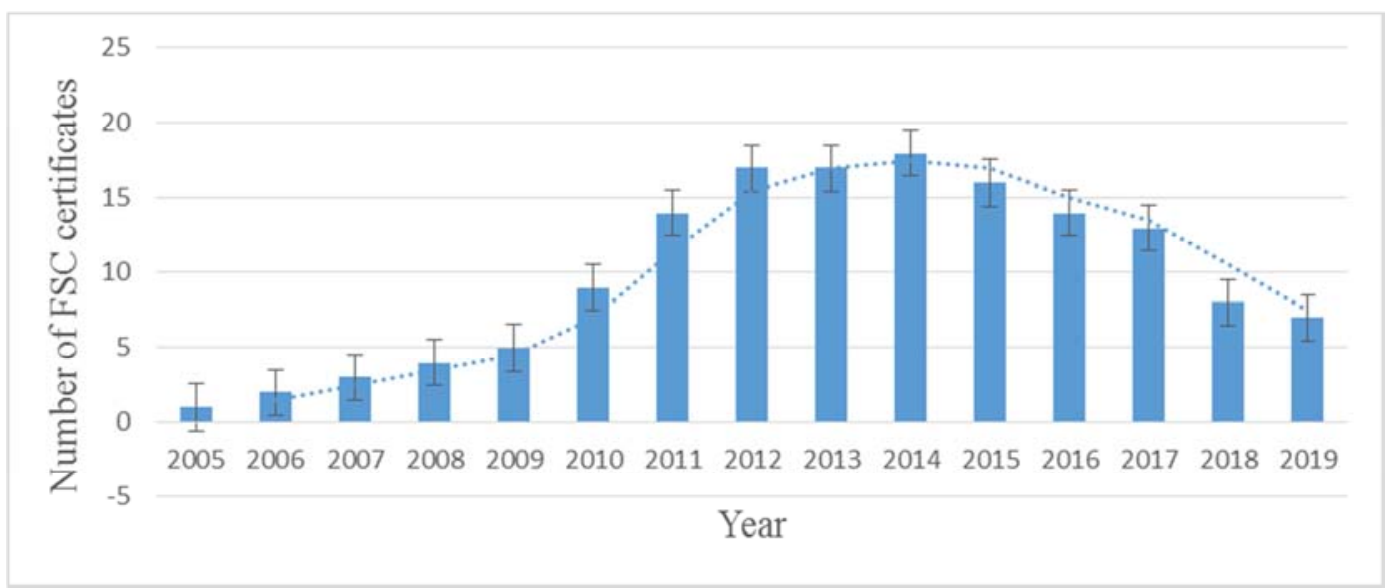

FSC, Fact and Figure, 2012-2019.

Figurer 3. FSC Forest Management (FM) and Chain of Custody (COC) number of certificates in Cameroon 2005-2019.

\section{Discussion}

\subsection{Dynamism in FSC certified area in Cameroon}

Forest Stewardship Council certification ensures the forest management is 1) environmentally appropriate-protecting and maintaining natural communities and high conservation value of forests, 2) socially beneficial-respecting the rights of workers, communities and indigenous peoples and 3) economically viable-building markets, adding best value and creating equitable access to benefits [21]. Information on approved FSC National and Regional Forest Stewardship Standards indicates national standards in Africa. Countries in Africa with approved national/regional standards include Cameroon (FSC-STD-CAM-01-2010-Cameroon Community SLIMF: approved in December 2010 and FSC-STD-CAM01-2012-Cameroon Natural and Plantations: approved in April 2012). It has been indicated that the Community small or low-intensity managed forest (SLIMF) Standard approved for Cameroon and the Natural Forest and Plantations Forest Standard approved for Ghana was reviewed with the transfer process into the revised principles and criteria. In light manner, the Natural and Plantations Forest Standard approved for Cameroon was transferred to the revised principles and criteria at the end of the International Generic Indicators (IGI) development process ${ }^{1}$.

The total FSC certified area in Cameroon has exceeded 1 million hectares with the certification of new areas managed by the Société Forestiere et Industrielle de la Doume, a Rougier subsidiary and participant in the WWF's global forest and trade network (GFTN). The newly certified areas, covered 285,667 hectares and was located in the Mbang area of eastern Cameroon, home to the Barka community among the oldest residents of Cameroon's rainforests. This marked the first substantial increase of FSC certified area in the Congo Basin in several years [21]. In 2014, five companies

1 https://ic.fsc.org/national-standards.247.htm. 
managing 14 FMUs are FSC certified, representing about 940,000 ha or an average of 67,000 ha per FMU. Hence,

about $65 \%$ of existing FMUs have an approved plan, while about $13 \%$ are FSC certified (Table 4 ).

Table 4. FSC certificates in Cameroon 2008-2013.

\begin{tabular}{|c|c|c|c|}
\hline Company & Forest Management Unit & Area (ha) & Year certified $^{\mathrm{a}}$ \\
\hline Pallisco, Assene Nkou, SODETRANCAM & $10-030,10-041,10-039,10-044,10-031 \& 10-042$ & 344,605 & 2008 \\
\hline Wijma & $09-024$ & 55,078 & 2008 \\
\hline Wijma & 09-021 & 41,965 & 2005 \\
\hline Wijma & 09-022 & 61,301 & 2010 \\
\hline CAFECO & $11-005$ & 80,800 & 2010 \\
\hline SFIL & $10-052$ & 69,008 & 2010 \\
\hline Rougier & $10-056$ & 73,660 & 2013 \\
\hline Rougier & $10-054$ & 144,750 & 2013 \\
\hline
\end{tabular}

a This refers to the first year in which a forest management certificate was awarded (i.e. there was no prior certification under a different name or by a different certifying body).

Source: Cerutti et al., 2014.

Data and information from the ministry of forestry and wildlife as well FSC international revealed that among all the certified companies in Cameroon, PALLISCO is the sole FSC certified company today.

\subsection{Evolution of FSC Forest Managements and Chain of Custody certificates in Cameroon 2005-2015}

The first FSC certificates was issued to a forest concession in Cameroon in 2005 (Groupe Wijma Cameroun). The FSC number of certificate increased from 1 concession in 2005 to 9 certificates in 2010. With greater awareness about forest certification in the ministry of forestry and its ministerial departments together with the exposure of forest concessions to the various facets of certification, the number of certificates in Cameroon increased to 17 in 2013 and to 18 in 2014. The number of FSC certified concession started witnessing a recession in 2015. The number of both Forest Management and Chain of Custody certificates dropped to 16 in 2015, 13 in 2017 and 7 in 2019 (Figure 3).

Table 5 presents FSC certified surface area in Cameroon from 2012 to 2019 . The surface area was 820,630 hectares from February 2012 to June 2012. The surface area witnessed a decrease in by 181,070 hectares in July and August 2012. The surface area later increased to 727,707 hectares (increase by 88,147 ha) from September 2012 to April 2013. FSC certified surface area witnessed an increase from May $2013(1,013,374$ hectares) to December 2014, an increment of 285,667 hectares. The surface area saw a drop to 940 , 945ha (72,429 hectares) from August 2015 to May 2017. June-November 2017 was a period of boom the FSC certified surface area in Cameroon $(1,130,301$ hectares). From this period of boom, the certified area dropped by from 715,883 hectares in December 2017; to 411,976 hectares between April and July 2018 and to 341,708 hectares from August 2018 to December 2019 (Table 5).

Table 5. FSC Forest Management (FM) and Chain of Custody (COC) certified surface area in Cameroon 2012-2019.

\begin{tabular}{|c|c|c|c|c|c|c|c|c|}
\hline \multirow{2}{*}{ Month } & \multicolumn{8}{|c|}{ FSC certified surface area (ha) } \\
\hline & 2012 & 2013 & 2014 & 2015 & 2016 & 2017 & 2018 & 2019 \\
\hline January & * & 727707 & 1013374 & * & 940945 & 940945 & 697643 & 341708 \\
\hline February & 820630 & 727707 & 1013374 & * & 940945 & 940945 & 697643 & 341708 \\
\hline March & 820630 & 727707 & 1013374 & * & 940945 & 940945 & 697643 & 341708 \\
\hline April & 820630 & 727707 & 1013374 & * & 940945 & 940945 & 411976 & 341708 \\
\hline May & 820630 & 1013374 & 1013374 & * & 940945 & 940945 & 411976 & 341708 \\
\hline June & 820630 & 1013374 & 1013374 & $*$ & 940945 & 1130301 & 411976 & 341708 \\
\hline August & 639560 & 1013374 & 1013374 & 940945 & 940945 & 1130301 & 341708 & 341708 \\
\hline September & 727707 & 1013374 & 1013374 & 940945 & 940945 & 1130301 & 341708 & 341708 \\
\hline October & 727707 & 1013374 & 1013374 & 940945 & 940945 & 1130301 & 341708 & 341708 \\
\hline November & 727707 & 1013374 & 1013374 & 940945 & 940945 & 1130301 & 341708 & 341708 \\
\hline December & 727707 & 1013374 & 1013374 & 940945 & 940945 & 715883 & 341708 & 341708 \\
\hline
\end{tabular}

*Unavailable data.

Source: FSC, Fact and Figure 2012-2019.

\subsection{Factors Impeding FSC Certification in Forest Concessions in Cameroon}

\subsubsection{Poor Demand for Certified Wood Within the Domestic Market}

FSC certifications in developing nations most at times generate considerable problems in the search for markets for their products because demand for certified timber in local markets is generally low $[30,31,3]$. Indeed, per the responses obtained, among the reasons impeding company's move for certification is the poor demand for certified products in the domestic market. This assertion suggests that, 
from the respondents' perspectives, the market available for certified forest goods was less than noncertified forest goods partly due to the higher prices of the former compared to the latter because of the costs associated with the certification scheme. Thus profit oriented companies may not see the added value for certification except adding costs of production particularly if their market focus is domestic. Thus, depending on the market, and to the extent that logging companies find local markets not demanding certified wood, they may not be compelled to seek certification [3].

\subsubsection{Socio-political Crisis in Cameroon and Shut Down of Certified Companies In Cameroon}

The two Anglophones Regions of Cameroon have been since October 2016 a conflict prone zone. The main impact of the ongoing armed conflict is the displacement of an estimated 351.000 people from their place of origin to nearby cities where they deem secured. Armed-conflicts between separatists commonly known and Ambazonians and Cameroon Military have induced displacements because of fear of targeted attacks by both parties involved in the conflict. There are rampant killings, engagement in banditry, burning of homes and villages, burning of schools and administrative structures, burning of shops and markets, kidnappings, rape and destruction of young food crops [32]. The socio-political crisis affected one of the certified concessions located in Eyumojock Sub-division, South West Region of the country. Forest concession number 1087 made up of FMUs 11005 was created as a temporal concession under Cameroon Agriculture and Forestry Exploitation Company (CAFECO) with a surface area of 80,800 hectares. The workers and administrative staff deserted the area for safety leading to a drop in FSC certified area. In addition, the French company Rougier with FMU 10-056 (73,660 hectares), FMU 10-038 (67,257 hectares) and FMU 10-054 (144,750 hectares) shut down in 2018 . This resulted to a fall in FSC certified surface area by 285,667 hectares.

\subsubsection{Reluctance from the Government}

Information from field interview indicated that the government of Cameroon was reluctant in accepting certification and legality schemes. The government officials with lack of knowledge in this sector thought that the certification and legality schemes were to replace the government (MINFOF) in forest management in Cameroon. In the $1990 \mathrm{~s}$, forest certification was driven by environmental NGOs (WWF, Greenpeace, Friends of the Earth and Fern) that were promoting the boycott of tropical timber in general and African timber in particular in the international markets. This was perceived by governments in central and western Africa as a process aimed, ultimately, at boycotting African timber in international markets and to be under the domination of those activist environmental NGOs. According to an informant (WWF), "FSC was introduced in Cameroon at a period when there was a poor governance system. This poor governance system in the forest sector was in relation to forest management, payment of workers and the payment of taxes. The government of Cameroon was reluctant in the implementation of forest certification because they thought FSC has as goal to replace her. In addition, the government of Cameroon is most often absent in many rural areas. The villagers most often demand a lot and put more pressure on logging companies. This has made several logging companies to spend hundreds of thousands to satisfy the indigenous people in order to maintain their certification status. Many companies are therefore scared to go in for FSC certification because of the pressure from the local people. Many new logging companies are not going in for FSC certification hoping to be affiliate to the new VPA/FLEGT. FSC was promoted by environmental NGOs such as WWF, Greenpeace, Friends of the Earth and these NGOs had a lot of conflicts with the government of Cameroon in the protection of biodiversity. These NGOs were advocating that concessions are destroying the forest which serves as a habitat for big mammals like gorillas, monkeys, chimpanzees, and others. The destruction of the habitat and poaching can result to the extinction of these valuable species". The reluctance from the state of Cameroon had negative impacts on the implementation of FSC certification and certified concessions in Cameroon.

\subsubsection{Illegal Logging and Corruption in the Forest Sector}

Illegal logging has long been recognised as a significant problem in Cameroon. Interviewees raised concerns over the misuse of certain logging permits in the country, and the lack of effective regulation and law enforcement. Logging without permit and rampant abuse of logging permits (Logging more than permitted volume, logging below the accepted diameter and logging out of the permitted logging area) feature strongly amongst the most prominent type of illegal logging within the Congo Basin [33, 34]. Illegal logging by large scale concessions is common practice and often characterized by logging without management plans, logging in prohibited areas, over logging, non-payment of fees and taxes [35,36]. Illegal logging increased from $40 \%$ to $65 \%$ between 2000 and 2012 in Cameroon, of which chain saw millers accounted for $50 \%$ of the total. [38]. Estimates of the illegal log harvested in 2006 in Cameroon was more than $540,000 \mathrm{M}^{3}$ [38, 39]. In Cameroon, 92\% of illegal logged timber by artisanal loggers was sold domestically in 2009 [22]. The ever-growing informal sector is a principal driver of illegal logging within the Congo Basin [40, 41]. This sector accounts for $50 \%$ of annual wood harvest for Cameroon. Illegal logging by private individuals is equally rampant within the region, they account for more than $200,000 \mathrm{~m} 3$ of illegal logged timber in Cameroon $[42,43]$. Illegal logging couple with corruption has a negative impact of certified concessions in Cameroon. This is due to the fact. That wood is readily available for buyers thereby reducing the marketing of certified wood and timber products.

\subsubsection{Availability of a Non-certified Asian Markets}

In 2001, the export of rough wood and wood related products to China represented $3.5 \%$ of total exports of the commodity by Cameroon. By 2005, this share has increased to almost $4 \%$. In terms of total exports to China, the share of 
Wood increased from $9 \%$ to about $24 \%$ between 2001 and 2005 [44]. Timber and wood products represented 21.9 percent of china's overall imports from Cameroon in 2008, of which 82 percent was raw wood. It has been argued that the volume of Cameroonian timber exported to China is a greater extent non-certified, illegal timber, compared to Cameroons timber exports to the European Union and the United States of America [45]. Information received from interviews indicated that majority of forest concessions in Cameroon do not go in for forest certification because there is a ready noncertified market in china and other Asian countries. This scenario discouraged many concessions from affiliating in certification, thus a reduction in FSC certificate and certified surface area in Cameroon. One of the factors that slowed down FSC certification in Cameroon was the absence of small certificate holders. The absence of small certificate holders such as community forest and agro-industrial plantations according to the respondents has contributed enormously in the drop in FSC certified surface area.

\section{Conclusion and Recommendations}

Analysis revealed that the number of Forest Management Units in Cameroon increased from 105 in 2004 to 120 in 2019 while surface area increased from 6,961,700 hectares in 2004 to 7,073,056 hectares in 2019; an increase of 111,356 ha. Five certification and legality schemes were identified Cameroon with different principles, criteria and matrix.

In 2018, out of 117 FMU in the country, 16 were jointly certified by FSC and OLB, 7 jointly certified by OLB and Rainforest Alliance (RA) while OLB had 20 certified concessions. The FSC number of certificate increased from 1 concession in 2005 to 9 certificates in 2010, 17 in 2013 and to 18 in 2014, however the number dropped to 16 in 2015,13 in 2017 and 7 in 2019. The certified surface area increased from 820,630 hectares in 2012 to $1,013,374$ hectares in $2013 / 2014$ and witnessed a drop to 940,945 ha in 2015 . The peak period was from June-November 2017 with 1,130,301 hectares while in $2018 / 2019$ the surface area reduced to 341,708 ha. The investigation shows that factors impeding FSC Certification in the Cameroon were mainly poor demand for certified wood within the domestic market; socio-political crisis in Cameroon and shut down of certified companies in Cameroon; reluctance of the government of Cameroon, availability of non-certified Asian market; illegal logging and corruption in the forest sector as well as the absence of small certificate holders. It is equally hoped that Cameroon the number and surface area of certified forest concessions can be increase if the following recommendations are applied:

Strong mechanisms need to be put in place by FSC International in Cameroon to ensure the continued participation of all the stakeholders, especially local NGOs and communities, in the sensitization of forest concessions about the advantages of FSC certification.

FSC International has to ensure meaningful involvement and collaboration of the Ministry of Forestry and Wildlife (MINFOF) and its ministerial departments in forest certification. Governance reform in the forest sector can emulate the example in Gabon to ask all FMU to be FSC certified in two years.

FSC international can follow-up local communities with community forest and facilitate their eventual certification. They should ensure that local communities and indigenous peoples are involved directly during the implementation phase.

The financial, administration procedures of FSC certification systems should be reduced to attract more forest concessions who have tilted their sale towards the Asian noncertified market.

\section{Author Contributions}

Nghobuoche Frankline designed the study, analyzed the data, and prepared the manuscript with contributions from the co-authors especially Tatuebu Tagne Claude and others who took part in the conceptualization of ideas, the methodology, fieldwork and the review of the manuscript.

\section{Funding}

This research was funded by the Regional Research Center for Sustainable Development (RReCSuD) grant number (2020RReCSuD002AB).

\section{Conflicts of Interest}

The authors declare that they have no competing interests.

\section{References}

[1] Pearce, D., Putz, F. E. and Vanclay, J. K. 2003. "Sustainable forestry in the tropics: panacea or folly?" Forest Ecology and Management, vol. 172, no. 2-3, pp. 229-247.

[2] Gerwing, J. J. 2002. "Degradation of forests through logging and fire in the eastern Brazilian Amazon," Forest Ecology and Management, vol. 157, no. 1-3, pp. 131-141.

[3] Nukpezah, D., Alemagi, D., Duguma, L., Minang, M., Mbosso, C. and Tchoundjeu, Z. 2014. An Examination of Forest Certification Status among Logging Companies in Cameroon. Hindawi Publishing Corporation International Scholarly Research Notices Volume 2014, Article ID 323014, 8 pp. http://dx.doi.org/10.1155/2014/323014.

[4] Jayasinghe, P., Allen, S. D., Bull, G. Q. and Kozak, R. A. 2007. "The status of forest certification in the Canadian valueadded wood products manufacturing sector," Forestry Chronicle, vol. 83, no. 1, pp. 113-125.

[5] UNECE/FAO. (2010). Forest Products Annual Market Review 2009-2010, Geneva Timber and Forest Study Paper 21, (United Nations, 2010). 113 pp.

[6] Rametsteinera, E. and Simula, M. (2003). Forest certification an instrument to promote sustainable forest management? Journal of Environmental Management 67 (2003) pp 87-98 www.elsevier.com/locate/jenvman. 
[7] Forest Stewardship Council, 2012. FSC Facts \& Figure. FSC. Bonn, Germany. http://info.fsc.org/. 12pp.

[8] Forest Stewardship Council, 2019. FSC Facts \& Figure. FSC. Bonn, Germany. http://info.fsc.org/. 12pp.

[9] Karsenty, A. 2019. Multi-functionality of forest landscapes in the Congo Basin: Toward Concessions 2.0? (CIRAD, France), 16pp.

[10] Doetinchem, N., Megevand, C., Braune, L., \& Dulal, H. (2013). Deforestation Trends in the Congo Basin Reconciling Economic Growth and Forest Protection. COMIFAC/. The World Bank. Working PaPer $2 \mid$ Logging. 33 PP.

[11] MINFOF, 2017a. Secteur forestier et faunique du Cameroun: faits et chiffres.

[12] FAO, 2014. Contribution of the forestry sector to national economies, 1990-2011, by A. Lebedys and Y. Li. Forest Finance Working Paper FSFM/ACC/09 (Food and Agricultural Organization of the United Nations).

[13] MINFOF, 2017b. Annuaire statistique 2017 du MINFOF.

[14] United Nations Statistics Division, 2020. UN Comtrade Database. (2020). Available at: https://comtrade.un.org/data/. (Accessed: 3rd June 2020).

[15] Yadav, M. (2016). Handbook on forest certification. The Energy and Resources Institute, New Dehli, India, TERI Press. 310pp.

[16] Nghobuoche, F. 2015. The exploitation of non-timber forest products for local livelihood in the Bamboko Forest Reserve, South West Region of Cameroon. Masters Dissertation, University of Yaounde I. 156pp.

[17] Cashore B, Auld G and Newsom D. 2004. Governing through markets. Forest certification and the emergence of non-state authority. New Haven \& London: Yale University Press.

[18] Cashore B, van Kooten GC, Vertinsky I, Auld G and Affolderbach J. 2005. Private or selfregulation? A comparative study of forest certification choices in Canada, the United States and Germany. Forest Policy and Economics 7: 53-69.

[19] Marx A and Cuypers D. 2010. Forest certification as a global environmental governance tool: What is the macroeffectiveness of the Forest Stewardship Council? Regulation \& Governance 4: 408-34.

[20] Cerutti, P. O. Lescuyer, G. Tacconi, L. Eba'a Atyi, R. Essiane, E. Nasi, R. Tabi Eckebil P. P. and Tsanga R. 2017. Social impacts of the Forest Stewardship Council certification in the Congo basin. International Forestry Review Vol. 19 (S2), 2017.

[21] WWF, 2013. FSC Certification in Cameroon surpasses 1 million hectares. Global Forest and Trade Network (GFTN).

[22] Cerutti, P. O., Lescuyer, G., 2011. The Domestic Market for Small-Scale Chainsaw Milling in Cameroon: Present Situation, Opportunities and Challenges. CIFOR, Bogor (Indonesia) (52 pp. Available online: http://www.cifor.org/publications/pdf_files/OccPapers/OP-61. pdf; accessed on December 14th, 2019).

[23] Cerutti, Paolo Omar and Tacconi, Luca 2008. 'Forests, Illegality, and Livelihoods: The Case of Cameroon', Society \& Natural Resources, 21: 9, 845-853. URL: http://dx.doi.org/10.1080/08941920801922042.
[24] World Resources Institute, 2007. Interactive forest atlas of Cameroon, Version 2.0. ISBN 1-56973-632-4 ENGLISH. 48 pp.

[25] World Resource institute, 2004. Interactive Forest Atlas of Cameroon. Version 3.0 Overview Report. http://creativecommons. org/licenses/by-nc-nd/3.0/.

[26] World Resources Institute, 2009. Cameroon's Forest Estate. Summary of land use allocation within the national forest estate in 2009. 1pp.

[27] World Resources Institute, 2014. Cameroon's Forest Estate. Summary of land use allocation within the national forest estate in 2014. 1pp.

[28] World Resources Institute, 2019. Cameroon's Forest Estate. Summary of land use allocation within the national forest estate in December 2019. 1pp. Cmr-data.forest-atlas.org.

[29] Sunderlin, W., Ndoye, O., Bikié, H., Laporte, N., Mertens, B., \& Pokam, J. 2000. Economic crisis, small-scale agriculture, and forest cover change in southern Cameroon. Environmental Conservation, 27 (3): pp284-290.

[30] Gu'eneau, S. 2006. "La certification de la gestion forestière au Brésil: Portée et limites des nouvelles formes de gouvernance privées," in 52e Congrès international des américanistes, Sevilla, Spain, 2006.

[31] Becker, S. M. and Laaksonen-Craig, S. 2006. "Barriers to forest certification in developing countries," in Proceedings of the Biennial Meeting of the Scandinavian Society of Forest Economics, L. Lars and B. Rosenquist, Eds., vol. 41, Scandinavian Forest Economics, 2006.

[32] ICG, 2017. Cameroon's Anglophone crisis at crossroad.

[33] Pandya, J., 2002. Logging - a Sustainable Future in Cameroon? WWF Forest for Life Program. Manuscript available online

at: http://www.wwf.or.th/about wwf/where we work/africa/new s/index.cfm?uNewsID=11521PEFC, 2019. PEFC global statistics. June 2019.

[34] Global Witness, 2004. SIGIF Report. Global Witness, London, the United Kingdom. Halvorsen, K., 1992. Methodology for social science. Student literature, Lund, Sweden. Hamilton Resources and Consulting, 2008. Alternative Tenure and Enterprise Models in Ghana: a Country-level Study. Rights and Resources Initiative Group, Washington DC, USA.

[35] Smith, W., 2002. "The global problem of illegal logging". ITTO Tropical Forest Update, Vol. 10, No. 1, pp. 3-5.

[36] Guertin, C. E. 2003. Illegal logging and illegal activities in the forestry sector: overview and possible issues for the UNECE Timber Committee and FAO European Forestry Commission. Quebec Wood Export Bureau. Canada. p. 12.

[37] Lawson, S. 2014. Methodology for Import-source Estimates of Illegally Sourced Wood Imports: Thailand, South Korea and India.

[38] MINFOF, 2006. Statistiques d'abattage-DF10 enregistreeSysteme Informatique de Gestion des Informations forestieres (SIGIF). Yaounde', Cameroon.

[39] Cerutti, P. O.; Nasi, R. and Tacconi, L. 2008. Sustainable forest management in Cameroon needs more than approved forest management plans. Ecology and Society 13 (2): 36. [online] http://www.ecologyandsociety.org/vol13/iss2/art36/. 
[40] DeFries, R. S. et al., 2002. Carbon emissions from tropical deforestation and regrowth based on satellite observations for the 1980s and 1990s. Proc. Natl Acad. Sci. USA 99, 1425614261.

[41] Global Witness, 2015. Urgent action required to cut trade and aid ties to logging companies that have paid millions to militia guilty of mass murder and war crimes. https://www.globalwitness.org/en/campaigns/forests/bloodtim ber/ accessed on December 25th, 2019.

[42] World Bank, 2002. A revised strategy for the World Bank Group, October 31, 2002, 48p.
[43] Amariei, L., 2005. Legal compliance in the forest sector: a case study of Cameroon. Final report. FAO, Rome.

[44] Khan, S. A. and Baye, F. M. 2008. China-Africa Economic Relations: The Case of Cameroon. Report Submitted to the African Economic Research Consortium (AERC).37pp.

[45] Wood trade Atlas data, (2009). Provided by the Trade Law Center for Southern Africa (TRLAC). Accessed on 15/07/2020 from www.tralac.org. 59pp. 